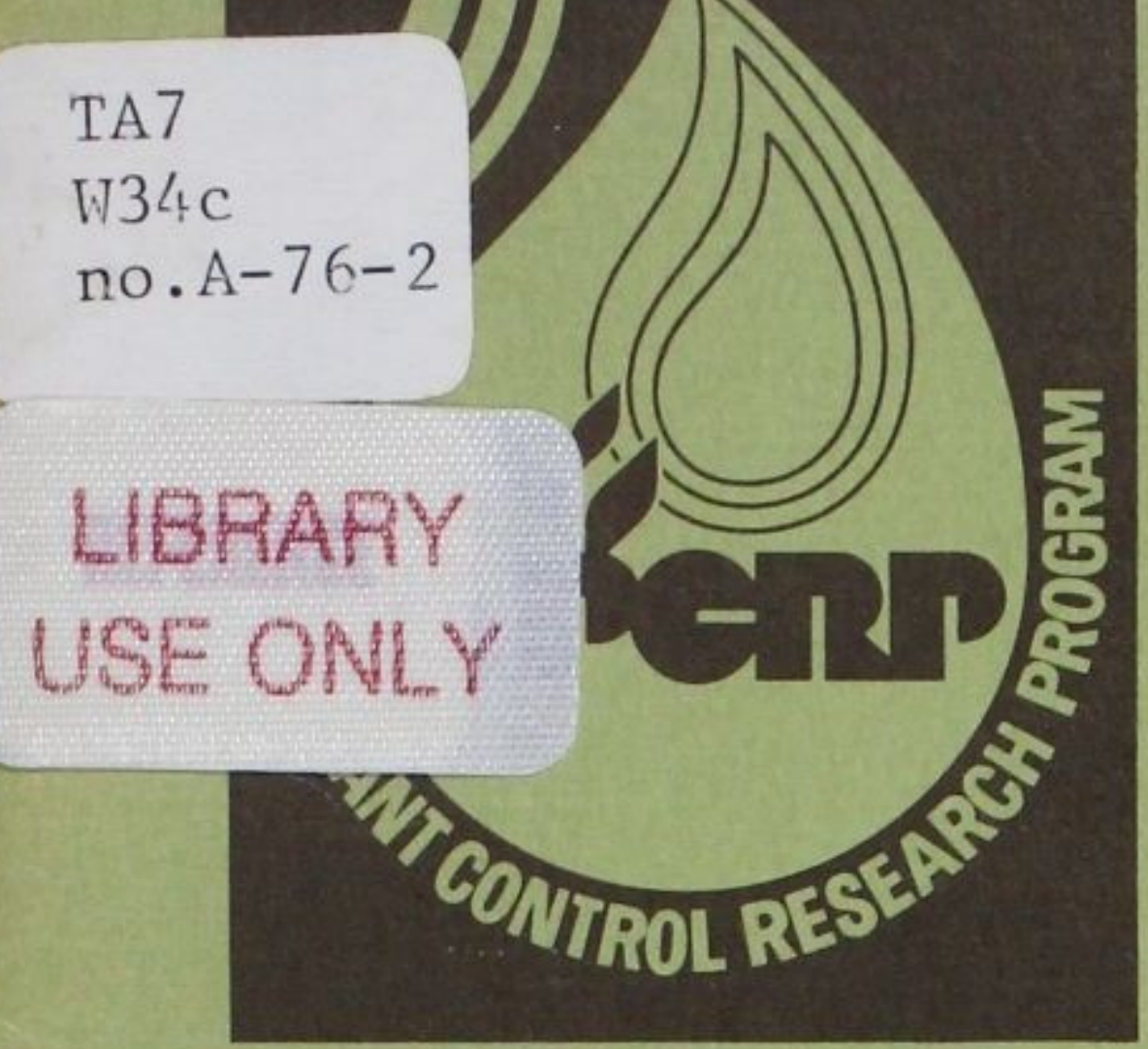

Property of the United States Govermode
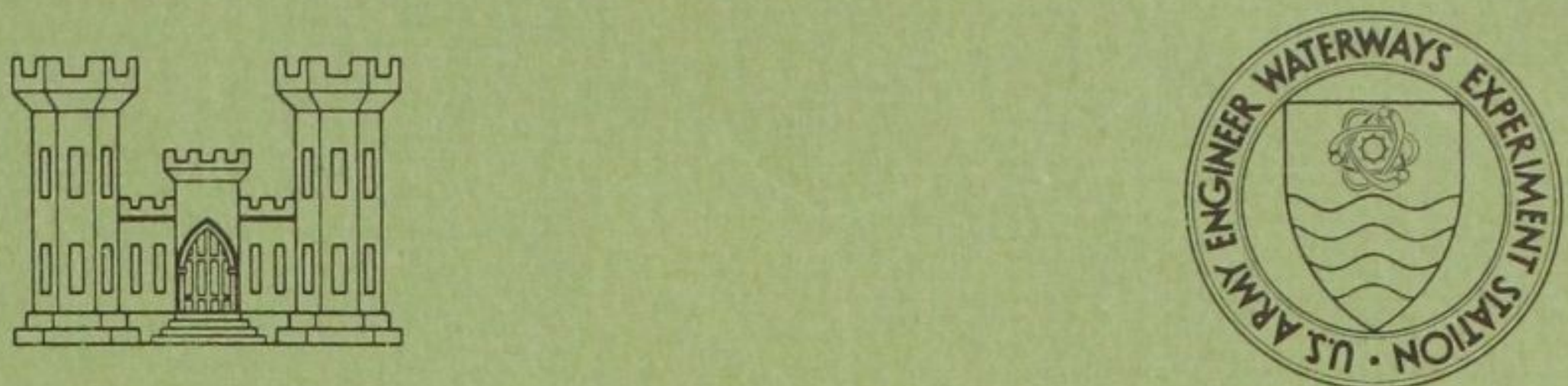

CONTRACT REPORT A-76-2

\title{
BIOLOGICAL CONTROL OF AQUATIC WEEDS WITH PLANT PATHOGENS
}

by T. E. Freeman, R. Charudattan, K. E. Conway, F. W. Zettler

Department of Plant Pathology

University of Florida

Gainesville, Florida

October 1976

Final Report

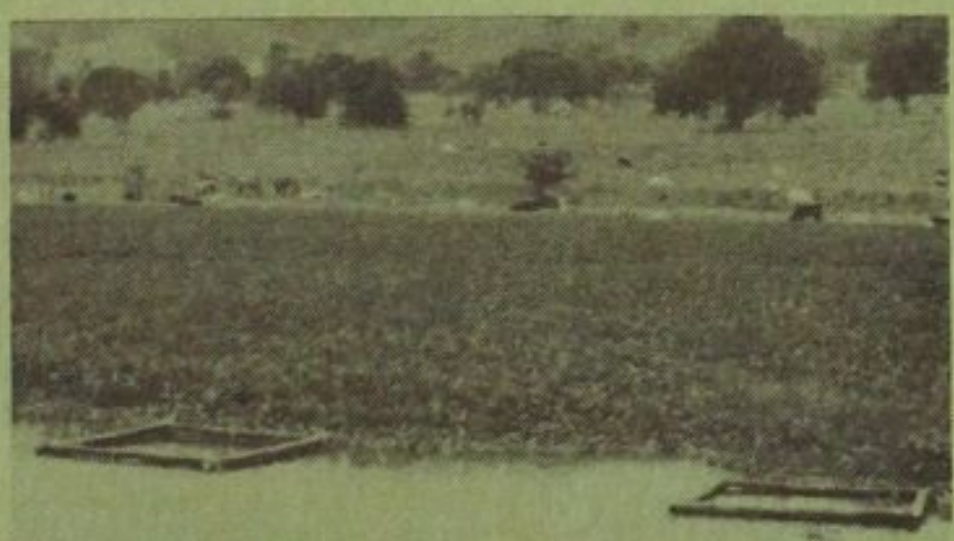

Approved For Public Release; Distribution Unlimited

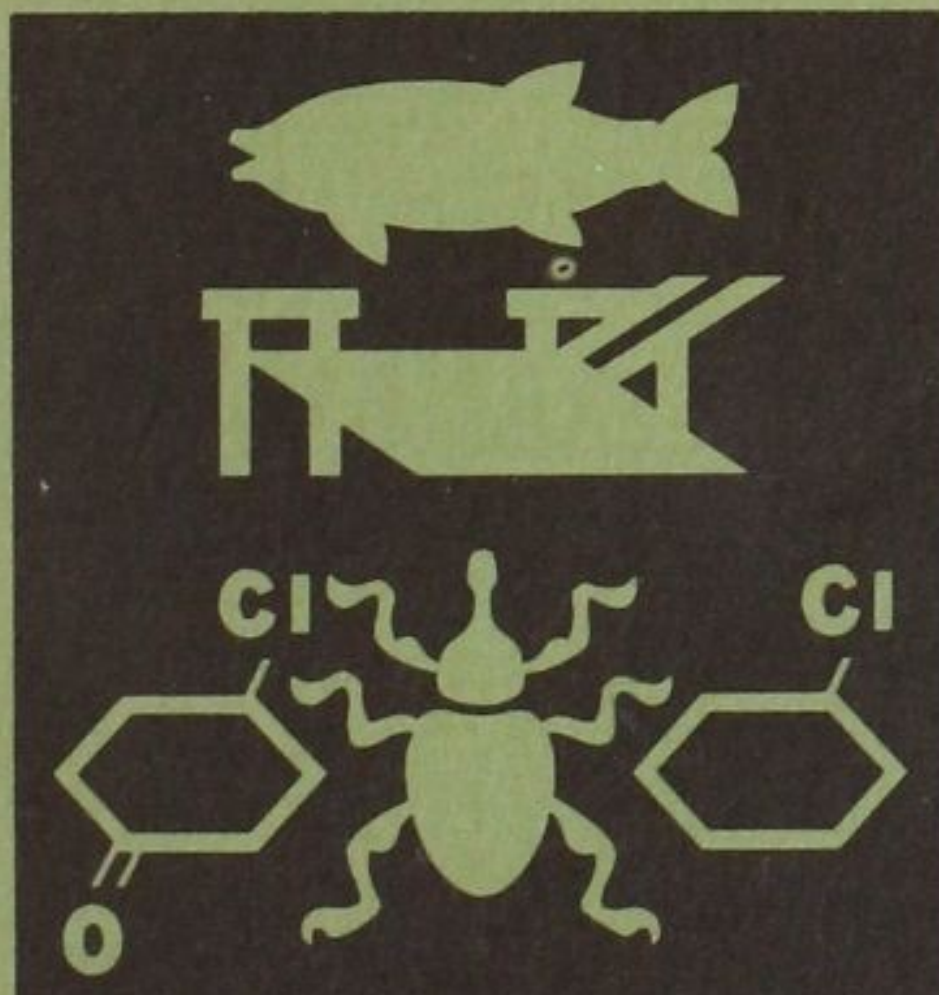

COBRATY BRAKCK

TECHNICAL INFORMATION CENTER

US ARMY ENGINEER WATERWAYS EXPERIMET

VICKSBURG. MISSISSIPPI

Prepared for Office, Chief of Engineers, U. S. Army

Washington, D. C. 20314

Under Contract No. DACW73-73C-0049

Monitored by Mobility and Environmental Systems Laboratory

U. S. Army Engineer Waterways Experiment Station

P. O. Box 631, Vicksburg, Miss. 39180 


\section{Unclassified}

SECURITY CLASSIFICATION OF THIS PAGE (When Data Entered)

\begin{tabular}{|c|c|}
\hline REPORT DOCUMENTATION PAGE & $\begin{array}{c}\text { READ INSTRUCTIONS } \\
\text { BEFORE COMPLETING FORM } \\
\end{array}$ \\
\hline $\begin{array}{l}\text { 1. REPORT NUMBER } \\
\text { Contract Report A-76-2 }\end{array}$ & 3. RECIPIENT'S CATALOG NUMBER \\
\hline \multirow[t]{2}{*}{$\begin{array}{l}\text { 4. TITLE (and Subtitie) } \\
\text { BIOLOGICAL CONTROL OF AQUATIC WEEDS } \\
\text { WITH PLANT PATHOGENS }\end{array}$} & $\begin{array}{l}\text { 5. TYPE OF REPORT \& PERIOD COVERED } \\
\text { Final report }\end{array}$ \\
\hline & 6. PERFORMING ORG. REPORT NUMBER \\
\hline $\begin{array}{l}\text { 7. AUThOR(s) } \\
\begin{array}{ll}\text { T. E. Freeman } & \text { K. E. Conway } \\
\text { R. Charudattan } & \text { F. W. Zettler }\end{array}\end{array}$ & $\begin{array}{l}\text { 8. CONTRACT OR GRANT NUMBER(8) } \\
\text { DACW73-73-C-0049 }\end{array}$ \\
\hline $\begin{array}{l}\text { 9. PERFORMING ORGANIZATION NAME AND ADDRESS } \\
\text { Department of Plant Pathology } \\
\text { University of Florida } \\
\text { Gainesville, Florida } 32601\end{array}$ & $\begin{array}{l}\text { 10. PROGRAM ELEMENT, PROJECT, TASK } \\
\text { AREA \& WORK UNIT NUMBERS }\end{array}$ \\
\hline \multirow{2}{*}{$\begin{array}{l}\text { 11. CONTROLLING OFFICE NAME AND ADDRESS } \\
\text { Office, Chief of Engineers, U. S. Army } \\
\text { Washington, D. C. } 20314\end{array}$} & $\begin{array}{l}\text { 12. REPORT DATE } \\
\text { October } 1976\end{array}$ \\
\hline & $\begin{array}{l}\text { 13. NUMBER OF PAGES } \\
25\end{array}$ \\
\hline \multirow{2}{*}{$\begin{array}{l}\text { 14. MONITORING AGENCY NAME \& ADDRESS(if different from ControllinB Office) } \\
\text { U. S. Army Engineer Waterways Experiment Station } \\
\text { Mobility and Environmental Systems Laboratory } \\
\text { Vicksburg, Mississippi } 39180\end{array}$} & $\begin{array}{l}\text { 15. SECURITY CLASS. (of this roport) } \\
\text { Unclassified }\end{array}$ \\
\hline & $\begin{array}{l}\text { 15a. DECLASSIFICATION/DOWNGRADING } \\
\text { SCHEDULE }\end{array}$ \\
\hline
\end{tabular}

16. DISTRIBUTION STATEMEN T (of this Report)

Approved for public release; distribution unlimited.

17. DISTRIBUTION STATEMENT (of the abstract ontered in Block 20, if different from Report)

18. SUPPLEMENTARY NOTES

Research was done in cooperation with and in support of the Florida Department of Natural Resources; U. S. Department of Interior; the Offices of Water Resources Research and Technology; and the Center for Environmental Program, University of Florida's Institute of Food and Agricultural Sciences. Dr. E. O. Gangstad, OCE, was the Contracting Officer's representative.

19. KEY WORDS (Continue on reverse side if necessary and identify by block number)

Aquatic plant control

Aquatic weeds

Biological control

Pathogens

20. ABSTRACT (Continue an reverse sidie if necoseary and tdentify by block number)

In the early 1970's, an effort was initiated to locate and isolate pathogenic organisms for use in the biological control of aquatic plants with special reference to waterhyacinth. This report describes the exhaustive search which has been conducted both in the United States and in several foreign countries. Information on laboratory and field research studies is presented as well as the current state of the art in this area of aquatic plant management research. 
THE CONTENTS OF THIS REPORT ARE NOT TO BE USED FOR ADVERTISING, PUBLICATION, OR PROMOTIONAL PURPOSES. CITATION OF TRADE NAMES DOES NOT CONSTITUTE AN OFFICIAL ENDORSEMENT OR APPROVAL OF THE USE OF SUCH COMMERCIAL PRODUCTS. 


\section{PREFACE}

The information presented herein was performed in part under Contract No. DACW 73-73-C-0049 with the Department of Plant Pathology of the University of Florida, Gainesville, Florida, for the Office, Chief of Engineers (OCE). The research was done in cooperation with and in support of the Florida Department of Natural Resources; the U. S. Department of the Interior; the Office of Water Resources Research and Technology, as authorized under the Water Resources Research Act as amended; and the Center for Environmental Program of the University of Florida's Institute of Food and Agricultural Sciences. This study was conducted and the report prepared by Drs. T. E. Freeman, R. Charudattan, K. E. Conway, and F. W. Zettler. Dr. E. O. Gangstad, OCE, was the Contracting Officer's representative for the contract; his assistance and constructive criticism is hereby acknowledged. The authors are also grateful to the many students and assistants who have contributed to the conduct of the work and preparation of the report. The Mobility and Environmental Systems Laboratory of the U. S. Army Engineer Waterways Experiment Station (WES), Vicksburg, Mississippi, monitored the report.

This report is considered to be a summary statement of the current state of the art of biological control of aquatic plants with pathogenic organisms. It describes the baseline or point of departure for future work in this vital research area of aquatic plant management.

Director of WES during the preparation and publication of this report was COL J. L. Cannon, CE. Technical Director was Mr. F. R. Brown. 


\section{CONTENTS}

$\underline{\text { Page }}$

PREFACE

CONVERSION FACTORS, METRIC (SI) TO U. S. CUSTOMARY AND

U. S. CUSTOMARY TO METRIC (SI) UNITS OF MEASUREMENT $\ldots \ldots \ldots \ldots \ldots \ldots .4$

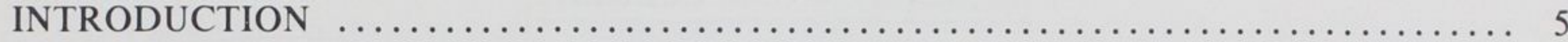

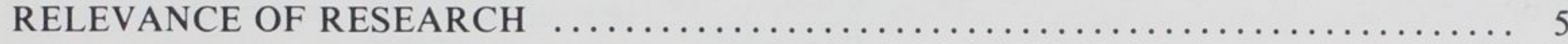

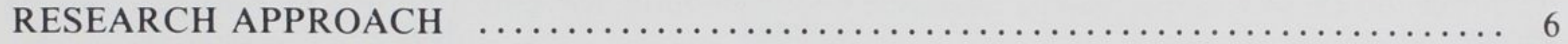

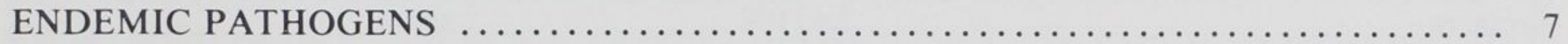

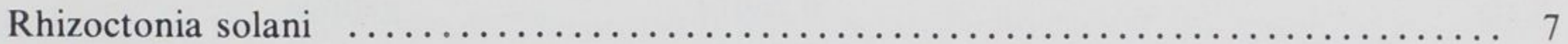

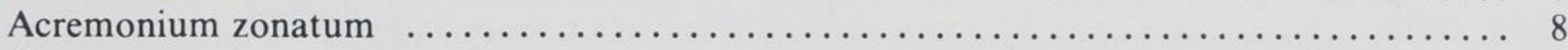

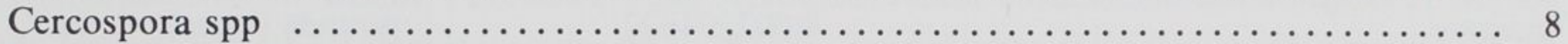

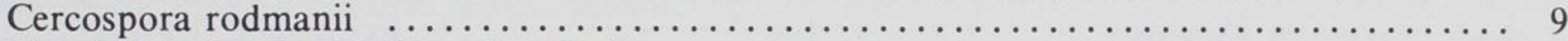

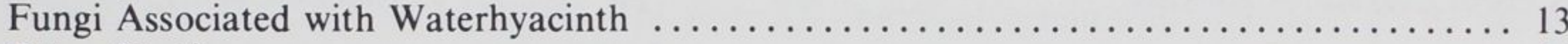

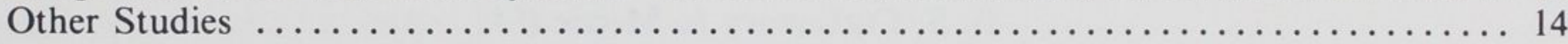

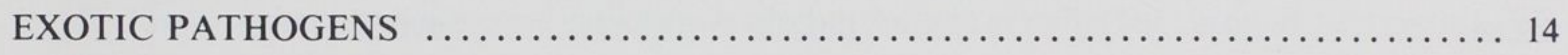

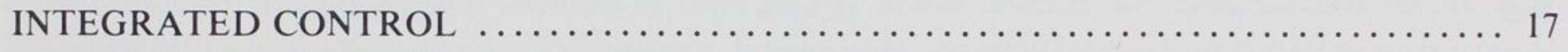

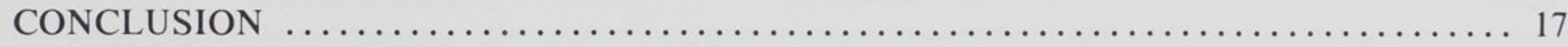

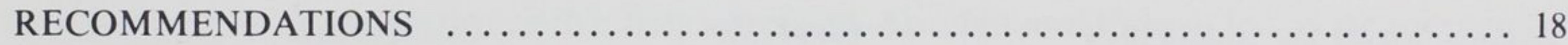

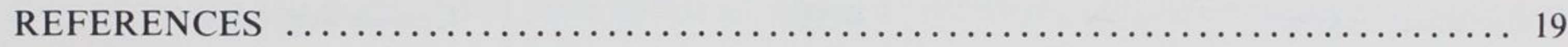

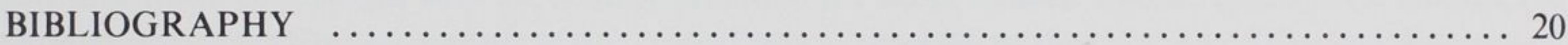

TABLES $1-4$ 


\section{CONVERSION FACTORS, METRIC (SI) TO U. S. CUSTOMARY AND U. S. CUSTOMARY TO METRIC (SI) UNITS OF MEASUREMENT}

Units of measurement used in this report can be converted as follows:

\begin{tabular}{l}
$\quad$ Multiply \\
\hline millimicrons \\
microns \\
metres \\
hectares \\
litres \\
cubic metres \\
grams \\
Celsius degrees or Kelvins
\end{tabular}

inches

feet

acres

gallons (U. S. liquid)

pounds (force) per square inch

Fahrenheit degrees

\begin{tabular}{c}
$\frac{\text { By }}{\text { Metric (SI) to U. S. Customa }}$ \\
\hline $0.03937 \times 10^{-6}$ \\
0.00003937 \\
3.28084 \\
2.47108 \\
0.26417 \\
35.31466 \\
0.002204622 \\
1.8
\end{tabular}

\section{U. S. Customary to Metric (SI)}

0.0254
0.3048
4046.856
0.00378541
6.894757
0.555

To Obtain

inches
inches
feet
acres
gallons
cubic feet
pounds (mass)
Fahrenheit degrees*
metres
metres
square metres
cubic metres
kilopascals
Celsius degrees or Kelvins**

* To obtain Fahrenheit $(F)$ temperature readings from Celsius $(C)$ readings, use the following formula: $F=(1.8)(C)+32$. To obtain Fahrenheit readings from Kelvins $(\mathrm{K})$, use: $\mathrm{F}=(1.8)(\mathrm{K}-273.15)+32$.

** To obtain Celsius $(\mathrm{C})$ temperature readings from Fahrenheit $(\mathrm{F})$ readings, use the following formula: $\mathrm{C}=(0.555)(\mathrm{F}-32)$. To obtain Kelvin $(\mathrm{K})$ readings, use: $\mathrm{K}=(0.555)(\mathrm{F}+459.67)$. 


\section{BIOLOGICAL CONTROL OF AQUATIC WEEDS WITH PLANT PATHOGENS}

\section{INTRODUCTION}

1. Plant pathogens have many characteristics that make them ideal candidates as biocontrols for aquatic weeds. ${ }^{1,2}$ They are numerous and diverse, frequently host specific, and easily disseminated and self-perpetuating. In addition, they will not completely eliminate a host species, and do not normally affect man or other animals. With these points in mind, a modest program was begun at the University of Florida at Gainesville in 1970, with the object of the evaluation and subsequent use of plant pathogens as biocontrol agents for aquatic weeds. The program was expanded with the aid of a matching grant from the U.S. Department of Interior's Office of Water Resources Research and subsequent support from the Florida Department of Natural Resources and the U. S. Army Corps of Engineers (Contracts DACW 73-71-C0002 and DACW 73-73-C-0049). The research described herein was conducted partly under Contract DACW 73-73-C-0049.

2. The program has progressed rapidly considering the lack of initial background information. We have developed a considerable backlog of information about diseases affecting aquatic plants. The objective of the utilization of plant pathogens in biocontrol programs for noxious aquatic plants has not yet been completely fulfilled. However, we have reached the critical stage when field evaluation of at least two pathogens of waterhyacinth is fully warranted. An additional three or four organisms should soon also reach this point. All of these efforts are aimed at waterhyacinths. We have also attempted to find and research diseasès with biocontrol potential for other aquatic weeds. To do these studies, we have requested continuing support of this critical area of research by the U.S. Army Corps of Engineers. Such support is vital in order to enable us to more completely reach our objective and to begin reaping the benefits of an operational biological control program in the shortest possible time.

\section{RELEVANCE OF RESEARCH}

3. The aquatic weed problem is one of considerable proportion that appears to be growing in magnitude rather than diminishing or even stabilizing. This is occurring despite the expenditure of considerable sums of money and human energy in the application of conventional methods of mechanical and chemical control.

4. The Florida Department of Natural Resources estimates over $\$ 15,000,000$ are expended annually in Florida for aquatic weed control. These control efforts are concentrated primarily on the estimated 100,000 ha* of water hyacinth (Eichhornia crassipes) and 40,000 ha of hydrilla (Hydrilla verticillata) that occur in the state. Lesser attention is given to the approximately 20,000 ha of other aquatic weeds, such as Eurasian watermilfoil (Myriophyllum spicatum) and alligatorweed (Alternanthera philoxeroides) (Burkhalter, personal communication). Despite these efforts, aquatic weed infestations have increased steadily in the years since these plants were introduced. The range of these plants has also expanded. Within the last 2-3 yr, Eurasian watermilfoil was found in the St. Johns

* A table of factors for converting metric (SI) units of measurement to U.S. customary units and U. S. customary units to metric (SI) units is presented on page 4 . 
River watershed, and hydrilla was found to infest Rodman Reservoir on the Cross Florida Barge Canal, Okeechobee, Orange, and Lochlossa Lakes.

5. Florida is by no means unique in having a tremendous aquatic weed problem. Proliferating water weed populations are of concern in the rest of the United States, Middle Europe, Africa, Asia, and South and Central America. Indeed the problem is worldwide, but is more acute in the warmer latitudes where waterhyacinth, hydrilla, watermilfoil, alligatorweed, salvinia (Salvinia spp.), and waterlettuce (Pistia stratioties) are the major offenders. Reasons for the increasing aquatic weed problem are complex, but are definitely related to man and his activities. With the increase in population and the accompanying environmental problems, it has become apparent that new methods of aquatic weed control must be found. Conventional methods have not been entirely satisfactory because of cost, overall ineffectiveness, or environmental pollution. The energy problem as it relates to fossil fuel supply has also served to emphasize the need for low-energy methods of control.

6. In recent years, biological control methods have received considerable attention. Various species of herbivorous insects, fish, snails, and even the manatee have been, or are being, investigated for their ability to exert some control pressure on noxious aquatic plants. Some of them, such as the alligatorweed flea beetle, have been reasonably effective, especially in an integrated control program. Surprisingly, until our program was initiated, plant pathogens had been rarely considered as biocontrol agents. They have all the prerequisites of a biocontrol agent and thus offer an untapped reservoir of potential usefulness, either alone or in an integrated control program with insects and, perhaps, chemicals. Our research efforts, the first $3 \mathrm{yr}$ of which are summarized in Reference 2, are aimed at bringing to fruition this use of plant pathogens in control programs for aquatic weeds.

\section{RESEARCH APPROACH}

7. We are using two approaches in our efforts to use plant pathogens to control aquatic weeds. They are:

a. The use of endemic or native plant pathogens as a type of "biological herbicide" through the artificial induction of epiphytotics. We consider this to be the most rapid approach from an operational standpoint.

$b$. The search for an ultimate utilization of exotic plant pathogens. This has been the classical approach successfully used by entomologists in their biological control efforts toward imported weeds. This facet involves the search for pathogens near the center of origin of the noxious species, in an area where climatic conditions are similar to those where the pest is a problem in this country. This is the slower of the two approaches from an operational standpoint.

8. During the past $3 \mathrm{yr}$, our efforts have been directed primarily toward those pathogens with definite biocontrol potential. These are: the endemic pathogens of waterhyacinth; Acremonium zonatum, Cercospora piaropi, C. rodmanii, Rhizoctonia solani, and three exotic ones; Bipolaris stenospila, Uredo eichhorniae, and Rhizoctonia sp. We have carried out extensive cultural studies in the laboratory; greenhouse studies, including cross-inoculation onto other plant species; host range studies; and in the case of the endemic pathogens, small-scale field tests. These latter tests have shown $A$. zonatum and C. rodmanii to have considerable potential as biocontrols. We are presently testing both of these at locations in Florida and in Lake Concordia in Louisiana. In this latter test, we have the two pathogens combined with two insects (Neochetina eichhorniae and Arzama densa) in all possible combinations. This test is being conducted in cooperation with the U.S. Army Corps of Engineers, U.S. 
Army Engineer Waterways Experiment Station (WES), and the U. S. Department of Agriculture (USDA) with the approval of the Louisiana Department of Agriculture and the Louisiana Fish and Game Commission. We believe $C$. rodmanii to have been the cause of a spectacular decline of waterhyacinth in Rodman Reservoir in 1971. This natural decline saved the U. S. Army Corps of Engineers approximately $\$ 35,000$ in spray cost in that body of water (Zeiger, personal communication). A. zonatum and N. eichhorniae combinations are also being tested in south Florida near Ft. Lauderdale.

9. Work with the exotic pathogens is being done in our quarantine facility, which is limited in size. Therefore, the work is progressing at a slower pace than with the endemic pathogens.

\section{ENDEMIC PATHOGENS}

\section{"Rhizoctonia solani"}

10. Fungal isolate RhEa from Panama was shown to be highly pathogenic to waterhyacinths. ${ }^{3}$ It was identified as a species of Rhizoctonia closely related to $R$. solani. We, therefore, deemed it advisable to test endemic isolates of this same fungus. Several isolates ${ }^{4}$ were found to be very nearly as pathogenic to waterhyacinth as was RhEa. An isolate from bean was selected (H287) for further study as a biocontrol agent. In the meantime, studies were continued under quarantine conditions with RhEa.

11. After completion of sclerotial survival studies with RhEa, we were convinced that the fungus had potential as a biocontrol agent for aquatic plants. Sclerotia of RhEa survived for over 26 months when submerged in lake water. Survival rate was probably longer, but the supply of sclerotia for testing purposes was exhausted after 26 months. The pathogenicity of cultures derived from submerged sclerotia was equal to that of the stock culture and cultures derived from dry sclerotia. ${ }^{5}$ In addition, it was shown that certain $R$. solani isolates were capable of attacking underwater portions of waterhyacinth and other aquatics. ${ }^{6,7}$ These later results were further encouragement to proceed with field tests of domestic isolates of $R$. solani.

12. On the negative side, $R$. solani possesses some distinct disadvantages. It is a common soilinhabiting parasite that affects numerous species of plants. Under ideal conditions for disease development, it will attack a large number of commercial crop plants (Table 1). Many consider this to completely preclude the use of this organism for biological control purposes. However, its use as a biological herbicide in the aquatic environment would not necessarily increase its potential as a pathogen of terrestrial plants. Indeed, when terrestrial crop plants were sprayed with inoculum of $R$. solani, fewer of them were attacked than when these same plants were inoculated under ideal disease conditions in the greenhouse (Table 1).

13. Initial field studies to assess the potential of domestic isolates of $R$. solani were begun in the fall of 1973. An isolate of Acremonium zonatum, formerly Cephalosporium zonatum, described by Rintz ${ }^{8}$ was also included in these studies. These fungi were used alone and in combination on a well-established stand of waterhyacinths in an isolated area of Lake Alice on the University of Florida campus. Both fungi were mass grown in liquid culture on a relatively simple chemically defined medium (Difco Czapeks-Dox broth amended with 0.5 percent yeast extract). Both fungi were grown in this manner, and the mycelial mats collected after 14 days. These mats were ground in a large commercial Waring blender. The resulting mycelial suspensions were sprayed on waterhyacinth plots in Lake Alice on 10 October. The two fungi were applied singly and in combination. Spraying was accomplished with a 12-gal conventional Broyhill sprayer at 100 psi. Plots were approximately $1 / 20$ of an acre.

14. Infection by $R$. solani was apparent in less than a week and with $A$. zonatum in less than two. 
By the first frost in early December, secondary spread of $A$. zonatum was apparent and resulting damage was significant. Lesions caused by $R$. solani persisted, but secondary spread was negligible and damage was less than anticipated. Plots were observed throughout the winter and into the following growing season. No evidence of $R$. solani infection the following spring was noted, whereas sporadic $A$. zonatum infections occurred. These results were disappointing in the case of $R$. solani, but not totally unexpected. The lack of a spore stage was a deterrent in secondary spread on aerial portions of the plant. On the other hand, results obtained with $A$. zonatum were more promising than laboratory and greenhouse studies had indicated. Thus, $R$. solani studies were curtailed in favor of more intense study on A. zonatum.

\section{“Acremonium zonatum"}

15. In addition to the field test (paragraphs 13-14) and host range studies (Table 1), we have conducted a wide variety of additional studies with the fungus $A$. zonatum. For instance, during the course of our preliminary work, it became apparent that the culture medium on which A. zonatum was grown affected its pathogenicity to waterhyacinth. Pathogenicity as well as total inoculum production was enhanced by enriching the culture medium. Pathogenicity increased as culturing medium was changed from cornmeal agar to Czapeks agar to Czapeks agar plus yeast extract to potato-dextrose agar to potato-dextrose agar plus yeast extract.

16. The fact that pathogenicity of $A$. zonatum changed due to culturing substrate brought forth the idea that other factors may also be used to increase pathogenicity. In at least one other plant pathogen, Cladesporium fulvum on tomato, virulence has been increased through irradiation of cultures with ultraviolet radiation. Short wave UV radiation in the $253-\mathrm{m} \mu$ range was most effective. Since this wavelength is germicidal, dosages were critical. A decision was made to embark upon a study of the effectiveness of UV radiation for inducing mutations for increased virulence to waterhyacinth in populations of $A$. zonatum. Thus far, we have isolated over 400 single spore cultures derived from spores irradiated with UV light $(253 \mathrm{~m} \mu)$ for periods ranging from 30 to $180 \mathrm{sec}$. Many of these cultures differ morphologically from the parent cultures.

17. So far, approximately 200 cultures have been tested for changes in their pathogenicity to waterhyacinth. Where changes have been noted, in most cases, there was a reduction in pathogenicity. However, in three or four cases, there appeared to be a slight increase in pathogenicity. The fact that some changes appear to have occurred is encouraging at this stage in these studies.

18. Additional field tests of $A$. zonatum were conducted during the summer of 1974 both at Gainesville and Ft. Lauderdale. In June of 1975, it was included, along with three other biotic agents, in an integrated control test in Lake Concordia.

19. Results with $A$. zonatum have been erratic. Infection appears to be related to the growth habit of the waterhycinth. Large robust plants seem to be more readily infected than smaller ones. Where infection does take place, subsequent spread by the pathogen is slow and does not keep pace with the prolific growth of the host. A. zonatum is most effective when used in an integrated system with insects and other fungi.

\section{“Cercospora” spp}

20. During the winter of 1973-74, waterhyacinth plants in the area of Gainesville were found affected by a leaf-spotting disease not previously noted. The disorder was found to be incited by a species of Cercospora subsequently identified as C. piaropi.$^{9}$ This was only the second report of the occurrence of this organism since it was originally reported from Texas in 1914. The other occurrence was in India. 
The fungus did not appear to be causing appreciable damage to the waterhyacinth plant at the time it was first noted.

21. In December 1973, Dr. Conway isolated, along with many other fungi, a Cercospora species from declining waterhyacinth in Rodman Reservoir. ${ }^{10}$ Preliminary tests showed the fungus to be pathogenic on water hyacinth, and a secondary test showed it to inflict considerable damage on this plant. In fact, affected plants eventually died and sank to the bottom of the test vats. Therefore, this fungus was programmed for more detailed laboratory study and eventual field testing.

22. Microscopic examination revealed the fungus to be a typical Cercospora. However, spore measurements showed the spores to be much longer than those recorded for C. piarop $i^{9}$ which is the only previously reported Cercospora on waterhyacinth. Spores of $C$. piaropi rarely exceed $150 \mu$ in reports of its occurrence, whereas those of the Rodman Cercospora frequently exceed $400 \mu$. In addition, symptoms caused by this fungus appear to differ from those recorded for $C$. piaropi. Symptoms caused by the former is a general blasting of the foliage, whereas the latter produces more discrete spots on the leaves. However, there was the distinct possibility that we were dealing with two manifestations of the same fungus and disease. When leaves exhibiting C. piaropi symptoms with fruiting characterized by small spores are brought into the laboratory and placed under moist conditions, long spores frequently develop on the dead tissue. Therefore, we were not sure if we had a long spore variant of C. piaropior a new waterhyacinth species of Cercospora (Cercospora spp. are distinguished by the host upon which they occur). Further study revealed that the spore not only differed in size but in basal morphology. These differences along with symptomology prompted its description as a new species of Cercospora designated $C$. rodmanii. ${ }^{11}$

\section{“Cercospora rodmanii"}

23. Optimum temperature for growth of C. rodmanii is near $20^{\circ} \mathrm{C}$; however, excellent growth occurs over the range of $20^{\circ}$ to $30^{\circ} \mathrm{C}$. Pathogenicity appears correlated with growth, but this has not been definitely determined. The fungus grows rapidly for a Cercospora reaching a maximum growth on potato-dextrose agar plus yeast extract in 10-14 days at $20^{\circ} \mathrm{C}$. It sporulates sparsely on waterhyacinthextract agar, but profusely on the dead leaf tissue in the laboratory, greenhouse, and field.

24. Temperature studies tended to indicate the fungus would more likely attack the plant during mild weather. Therefore, field studies were begun in the fall on established stands of waterhyacinth in an isolated area of Lake Alice. An initial application was made 4 September 1974. Infection took place within two weeks, but subsequent spread was slow and a second application was made 3 October 1974 (Figure 1). Inoculum consisted of the mycelial growth from 60 Roux bottles cultured for two weeks (approximately $1000 \mathrm{~g}$ wet weight).

25. By mid-November, extensive damage had occurred in the immediate area sprayed, and spread was apparent around the entire perimeter of the lake (Figure 2). By the first frost on 2 December, considerable damage was apparent in areas of secondary spread, and spore trappings of the fungus were made at considerable distance from the original inoculation site, indicating extensive secondary spread. After this first frost and subsequent ones on 9 and 17 December, it was apparent that diseased plants were more severely damaged than more healthy ones. It should be noted that all these frosts were relatively light and healthy plants were not severely damaged. Above-average temperatures occurred in the latter part of January and February 1975, and some of the waterhyacinths began sending out offshoots. Evidently the apical meristem of the plants had not been killed, and the plants were able to resume growth. However, it was apparent that a severe stress had been placed on the waterhyacinths 

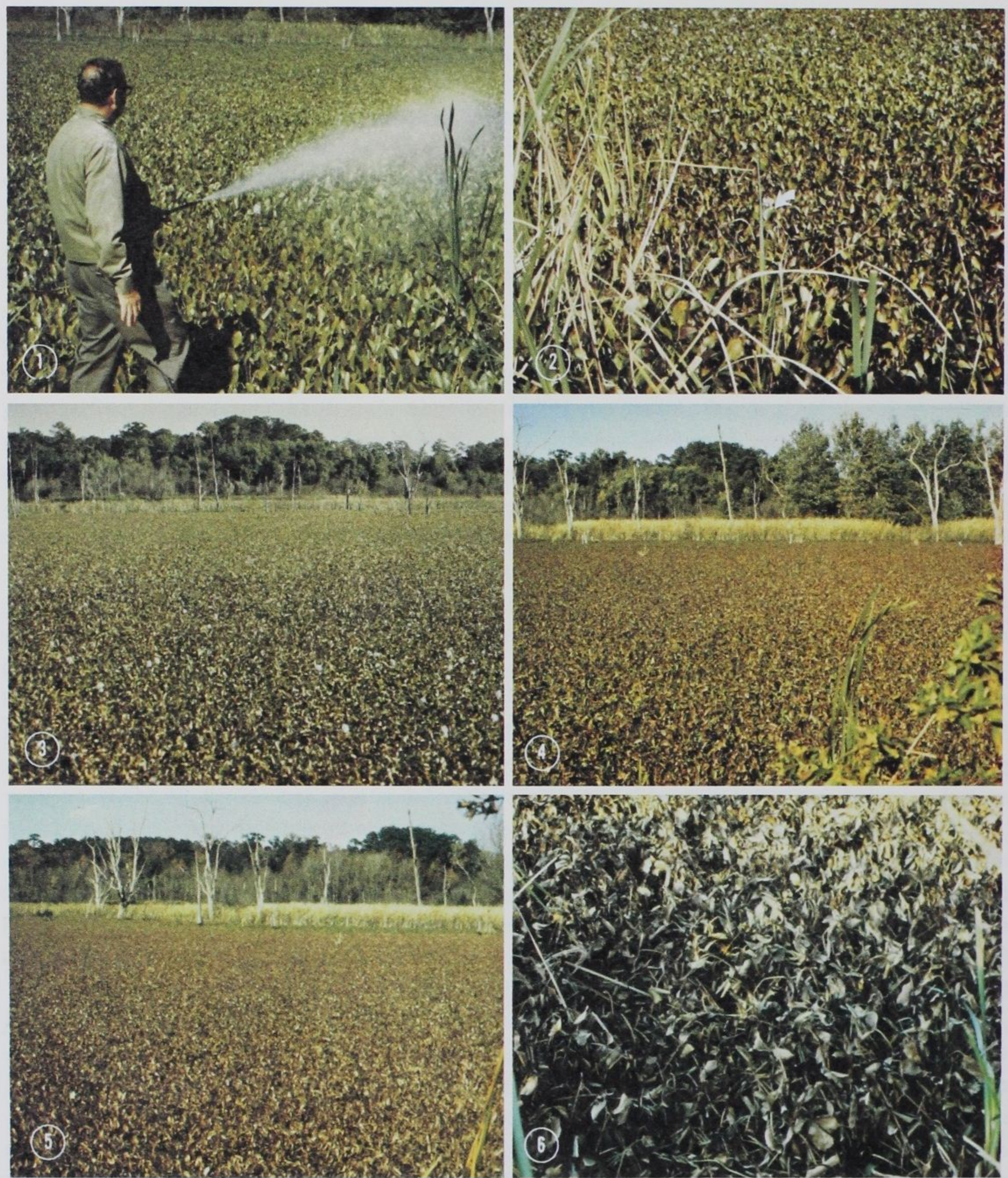

Figure 1. The damage resulting from inoculation of waterhyacinth with a Cercospora sp. in an isolated area of Lake Alice. (1) Application of fungus to healthy waterhyacinth on 3 October 1974. (2) Area of immediate spray (arrow) showing initial damage on 15 October 1974. (3) Overall area viewed from inoculation site on 13 November 1974. (4) Same view as (3) on 21 November 1974. (5) Same area on 17 December 1974, after three light frosts. (6) Closeup of diseased and frosted plants on 6 December 1974 

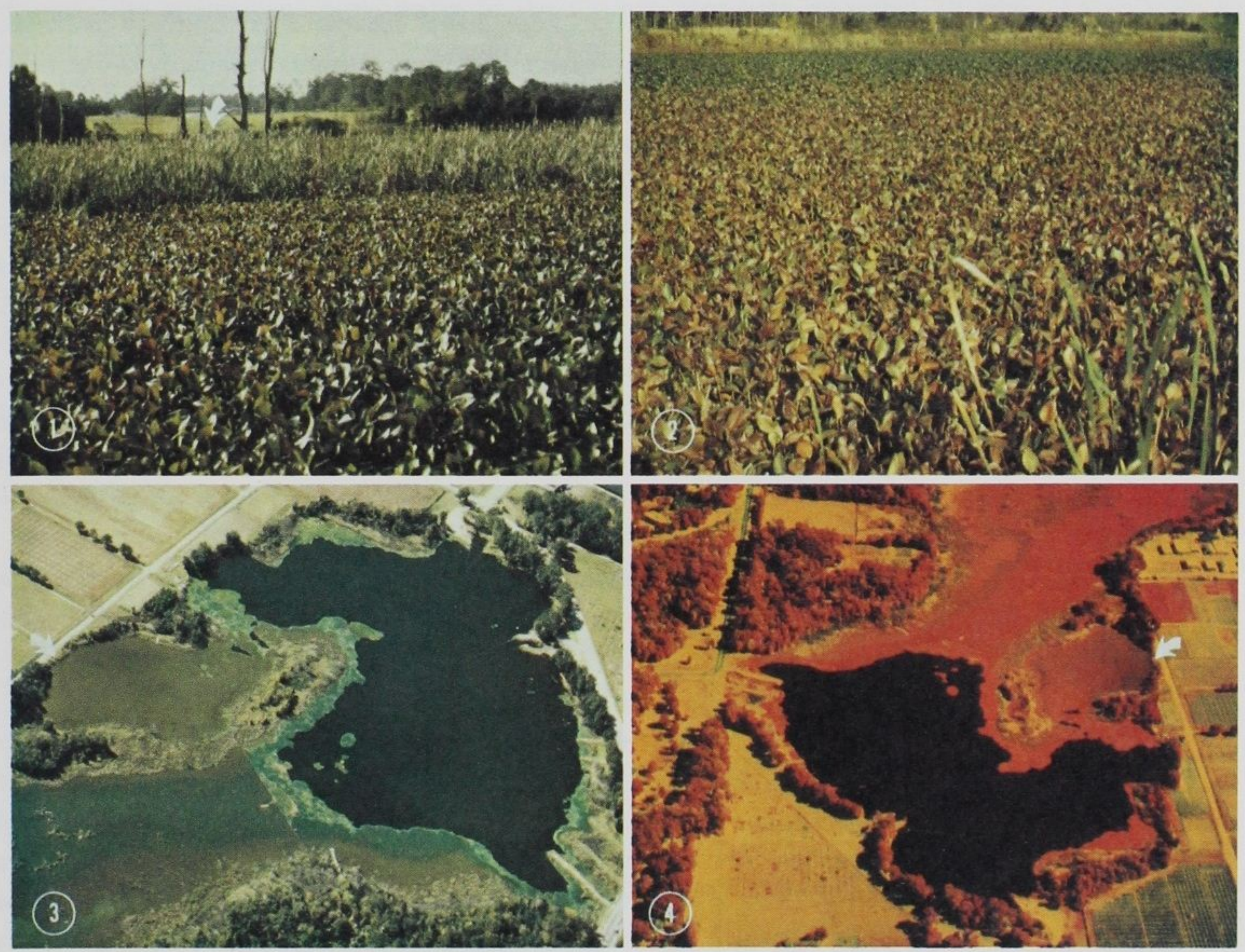

Figure 2. Spread of Cercospora sp. on waterhyacinth in Lake Alice after 3 October 1974 application. (1) Initial spread from inoculation site (arrow) through sawgrass barrier into main body of lake on 13 November 1974. (2) View from sawgrass barrier looking toward main body of lake on 18 November 1974. (3) Aerial view showing spread of disease from initial inoculation site (arrow) around entire perimeter of lake on 21 November 1974. (4) Color IR photo of lake on 21 November 1974. Diseased waterhyacinths are brownish-red whereas healthy ones are bright red 
when the plants in the pool area, which were normally 2-3ft tall, were less than 6 in. high. In comparison to these plants, waterhyacinths in the main lake where the disease was less severe were their normal 3-4 $\mathrm{ft}$. Thus, $C$. rodmanii fulfills the purpose of a biological control organism for waterhyacinths by increasing the stress on the plant and not necessarily eliminating the entire population.

26. We wanted to know what effect infection would have on the plants over a period of time. Four more sprays were applied on the pool area, two in March and one each in May and July.

27. In April, we were able to determine that most of the small waterhyacinths in the pool were infected again with $C$. rodmanii. However, with the approach of summer, the waterhyacinths began their rapid growth phase, and by June, the new leaves were outgrowing the disease. The infection of $C$. rodmanii during the summer was confined to the older, lower leaves. This condition prevailed throughout the summer until September when the waterhyacinth growth was slowed by cooler night temperatures. Increased infection was now apparent in the pool area. The waterhyacinths in the pool area showed a general browning by mid-September. This browning has continued into October until definite disease symptoms could be seen on the plants throughout the pool. Damage to waterhyacinth was approximately one month ahead of last year, and we were looking for increased damage this fall and winter. We will not be able to totally evaluate the extent of damage until the end of the 1976 growing season.

28. This disease that occurred in Lake Alice as a result of our inoculation with $C$. rodmanii is strikingly similar to the Rodman disorder noted in 1971 and to a lesser extent in 1972-1973. Dave Bowman, Reservoir Manager, observed the disease in Lake Alice and believes what he saw to be the same disease he had observed in Rodman. In addition, the root-rotting phase so notable in Rodman has begun to appear in Lake Alice. We now believe $C$. rodmanii to be the causal agent of the Rodman disorder.

29. Encouraged by the success in Lake Alice last fall, test plots were set up in Rodman Reservoir. A site was chosen behind tree population No. 4 to exclude outside interference with the tests. The purpose of this experiment was to reestablish the disease in the reservoir. Although the disease was very prevalent in 1971 , its severity on the waterhyacinth population has lessened each year.

30. Five sprays were to be applied from the shoreline, one every two weeks. The multiple sprays were felt necessary to begin infection and to increase the inoculum to a high enough level to create an epiphytotic. Spray operations were begun on 28 February 1975. The next day, the U. S. Army Corps of Engineers began to raise the water level of the reservoir from its winter draw-down depth of $4.67 \mathrm{~m}$ to a level of $5.49 \mathrm{~m}$. The water level had risen, and the waterhyacinths were growing and floating free of the shoreline by the second spray date. By the third spray application, the spray plots were moving with the rising water; therefore, one of our objectives of increasing the inoculum in one area could not be achieved.

31. In mid-April, damage on the plants due to $C$. rodmanii was present along a gradient from the opening onto the reservoir from tree population No. 4 to our spray site onshore. By this time, there was a definite reduction in plant growth in our plots when compared to the untreated waterhyacinths that surrounded these areas. In addition to the disease in the tree population No. 4 area, there was also a heavy natural infection of $C$. rodmanii in the main part of the reservoir in the Orange Springs and Blue Springs areas.

32. During May, the disease in the main reservoir continued to stress and brown the waterhyacinths. On May 30, another spray plot was established in the Cypress tree stand in tree population No. 4. 
33. In June, the waterhyacinths in the Orange and Blue Springs areas were completely browned. The symptoms on the plants were typical for $C$. rodmanii damage.

34. By July, the waterhyacinths in the Cypress stand were beginning to brown at the tips of the leaves, and in mid-July, the waterhyacinths in our original spray plots were showing the typical $C$. rodmanii symptoms. Waterlettuce was invading soon after the severely infected waterhyacinths died and sank to the bottom. By late July, the waterhyacinths in the Cypress stand were also dying out and open water was beginning to show.

35. On 7 August, aerial inspection of the original spray site showed continued browning and drop out of the waterhyacinths. In the Cypress tree area, there was now 10-20 acres of open water. By midAugust, the estimate of open water in the Cypress tree area exceeded 20 acres. Large mats of waterhyacinths showed typical symptoms, which included many dead plants with floating, spindly petioles and leaves. It was also noted that completely dead plants continued to float until broken apart by wind and water action.

36. By mid-October, the area of open water was estimated to be $35-40$ acres, with an additional 20 acres invaded by waterlettuce. The area now is aesthetically pleasing.

37. Results with $C$. piaropi have been very encouraging and it is programmed for more intense study. The host range tests (Table 2) were especially encouraging as they indicate the fungus to be highly host specific.

38. The field symptoms of $C$. rodmanii suggested that toxin may be involved. Symptoms were typical of those incited by toxic by-products in other disease syndromes. However, studies conducted by a graduate student, Mr. Ray Martyn, did not verify the presence of a toxic product in culture filtrates of the fungus.

39. We have carried out limited epidemiological studies. Extensive spore trappings were conducted in Lake Alice during the fall of 1975, when temperature variations ranged from below freezing at night to day temperatures in the eighties. Results show that sporulation by $C$. rodmanii was curtailed by temperatures below $50^{\circ} \mathrm{F}$. Maximum occurred when day temperatures were in the 70 - to 85-deg range. On 8 December 1975, spore trappings reached a high of 193 spores per cubic metre of air volume. Laboratory studies failed to reveal a forceable discharge mechanism for spores of $C$. rodmanii. Therefore, both spore release and subsequent dispersal is probably passive in nature.

\section{Fungi Associated with Waterhyacinth}

40. In November 1973, an active research project was initiated when Dr. Conway joined the project to catalogue the mycoflora found on waterhyacinths. His specific assignment was to study the mycoflora associated with declining waterhyacinths in Rodman Reservoir. The mycoflora can be divided into two main categories: those occurring on living tissue and those occurring on declining tissue (Table 3).

41. The fungi that occur on living tissue are studied for their possible role in the control of the prolific waterhyacinths. Fungi identified and cultured in this group include (a) AscomycetesMycosphaerella sp., Didymella sp., Leptosphaerulina sp., and Asteromella sp.; and (b) Fungi Imperfecti-Ascochyta sp., Cercospora sp., Phoma sp., Myrothecium striatisperum, and Cephalosporiopsis sp.

42. Fungi associated with dead and declining tissue include (a) Fungi Imperfecti-Curvularia lunata var. aeria, Alternaria sp., Dendryphion sp., Nigrospora sphaerica, Nigrospora oryzae, Thysanophora longispora, Periconca sp., Scolecobasidium constrictum, Penecillium spp., Tilletiopsis sp., Fusarium sp., Pestalotia sp., Botryodiploidea sp., Acremonium zonatum, Memnoniela sp., Epicoccum sp., 
Cladosporium spp., Pithomyces chartatum, Aspergillus spp., an unknown synematal fungus, Rhizoctonia sp. and Pyrenochaeta sp.; (b) Phycomycetes-Mucor sp. and Circinella sp.; and (c) Ascomycete-Melanospora sp.

43. The role of saprophytic fungi is often neglected in disease research; however, several important contributions to our knowledge of waterhyacinth control and utilization can be realized through their investigation. Periconia is a saprophytic fungus that produces a toxin which causes disease symptoms on certain plants. When the fungus is inoculated onto the waterhyacinth, a leaf spot is produced with the fungus continuing to grow on the leaf. The presence of Aspergilli and Penecillia may indicate the production of aflatoxins on the waterhyacinth. This is obviously important to researchers attempting to use waterhyacinths as a food source. The presence of Pithomyces chartarum is of even greater importance to nutrition researchers. It is the only fungus known to have caused a natural widespread outbreak of poisoning. The toxin, sporidesmin, causes liver damage, loss of weight, icterus, and photosensitivity to grazing animals. An additional project has been initiated through our department in cooperation with the Department of Animal Science Nutrition Laboratory and the Department of Veterinary Science to study mycotoxins present in waterhyacinths and their effect on animals. Thus, our efforts in determing mycoflora that may have biological control potential may also provide valuable information for workers concerned with other methods of control and utilization of the waterhyacinth.

\section{Other Studies}

44. Less extensive studies have been conducted with several other endemic pathogens of aquatic plants. These were concerned primarily with minor pathogens of waterhyacinth and the alligatorweed stunt virus. ${ }^{12}$

45. Repeated attempts to transmit the alligatorweed stunt virus by mechanical means and insects were unsuccessful. However, it was transmitted by grafting of healthy and diseased stock. Such a method of transmission limits this agent's usefulness as an effective biocontrol. It does prove conclusively that the malady is viral induced and not a genetic abnormality. Dr. Zettler is convinced that the virus belongs in the beet yellows group and may actually be a strain of beet yellows. Being in this group could present problems in clearing this virus for use as a biocontrol, since tristeza virus of citrus also belongs to the beet yellows complex.

46. Two other minor pathogens have been reported affecting waterhyacinth in Florida. There are a Sigmoidea sp. ${ }^{13}$ and Mycoleptodiscus terrestris. ${ }^{14}$ Both appear to be weak pathogens of little potential in biological control. A new nonpathogenic fungus of the genus Doratomyces was also recovered from waterhyacinth foliage. ${ }^{15}$

\section{EXOTIC PATHOGENS}

47. Dr. Charudattan has traveled extensively in search of exotic pathogens on waterhyacinth and hydrilla. In 1973, he spent 90 days in India (supported by the Florida Department of Natural Resources) collecting pathogens on these two plants. The regions in India surveyed included Sringar (State of Kashmir), the surroundings of Delhi and Calcutta, Dehra Dan Utter Pradesh, Kota (Rajasthan), and several areas in the state of Orissa. These areas were not covered during his previous tour in India from November 1971 to February 1972. In addition, several previously surveyed areas around Madras were revisited. One hundred and eighty-two fungal and bacterial isolates were obtained from hydrilla, waterhyacinth, waterlettuce, and miscellaneous submersed aquatic plants. Ninety-five were from hydrilla and the remainder from other plants. 
48. Twenty-four of the Indian hydrilla isolates proved to be pathogenic to hydrilla. These were primarily species of Penicillium, Aspergillus, and Trichoderma. These were pathogenic through the production of toxic metabolites. ${ }^{16}$ These toxic agents were identified as oxalic acid and penicillic acid. They are general toxic agents not specific for hydrilla. Thus, their direct use in a biocontrol program appears limited.

49. Fourteen of the remaining isolates were found to be pathogenic to waterhyacinth. Among these were isolates of Mycothesium roridum, Alternaria eichhorniae, and Acremonium sp. The others have not been identified because they are weakly pathogenic and are of academic interest only. The three pathogens have been evaluated and rejected as biocontrol agents in India. Nevertheless, we are maintaining them for a possible future role here in the United States.

50. Dr. R. Charudattan undertook two survey tours during the first quarter of 1974 . The first trip was to the Dominican Republic from 11 to 16 February. On this survey tour, about 82 fungal and bacterial isolates from diseased waterhyacinths were collected. The genera of fungi collected included Helminthosporium, Phoma, Macrophoma, Colletotrichum, Fusarium, Chaetomium, Pestalotia, and Alternaria. Unfortunately, the rust and smut diseases of waterhyacinth reported to occur in this country were not found. The second trip was to Venezuela between 3 and 12 March and yielded a collection of approximately 87 cultures. The majority of these are fungi, but they are yet to be identified. Pathogenicities of about 35 isolates from the Dominican Republic have been tested on waterhyacinth. So far, a species of Phoma and two species of Helminthosporium have been found to be virulent on waterhyacinth. One of the species of Helminthosporium is extremely pathogenic on waterhyacinth. This appears to be a hitherto unreported pathogen of waterhyacinth. Preliminary tests indicate it to be comparable in pathogenicity to Acremonium zonatum and Rhizoctonia solani. Among the diseases found in Venezuela was a necrotic leaf spot surrounding each feeding injury caused by the insect, Neochetina. Diseases of alligatorweed or Pistia were not encountered, though these plants were found in these countries. Several new and useful contacts were established in the two countries.

51. Dr. Charudattan traveled to Argentina and Uruguay during the last half of April 1974 in search of diseases on waterhyacinth and alligatorweed. On this trip, he was successful in finding the rust disease on waterhyacinth, but was unsuccessful in locating rust of alligatorweed. The rust on waterhyacinth was present in Argentina but not in Uruguay, where it had been reported to flourish. He was able to bring back adequate material for critical study in our isolation greenhouse.

52. Morphologically the rust fits the description of Uredo eichhorniae. This fungus was originally recorded on waterhyacinth in the Dominican Republic in 1927. The organism has been loosely referred to as Puccinia eichhorniae. No basis for this name has been established, since only the uredial stage of this rust is known. The material from Argentina did not have teliospores, and they have not formed in material brought back to Gainesville. We have been able to infect plants in the isolation greenhouse with the rust. Therefore, we should be able to maintain the culture and increase it for further study.

53. Considerable work remains to be done before we can determine if this disease has biocontrol potential. It did not appear to be causing significant damage on waterhyacinth in Argentina. However, this does not rule out the possibility that it will cause significant damage on the host in Florida. A different host gene pool may exist here that has not had the selection pressure of the disease exerted upon it. This we will soon determine. The big advantage of rust diseases is their host specificity. However, some rust species can affect related plant species and many have alternate hosts in nonrelated plant groups. Presently we do not have information concerning additional related hosts or alternate hosts of U. eichhorniae. Dr. Charudattan did find a similar rust on Pontederia sp. growing in close proximity to 
infected waterhyacinths. A similar rust also occurs on Pontederia in Florida. ${ }^{17}$ Cross-inoculation studies with these two rusts are presently in progress.

54. One additional exotic pathogen was added to our collection during 1974. This was a species of Alternaria isolated from leaf spots on alligatorweed from Puerto Rico. Diseased material was collected and transferred to us by Mr. Chuck Zeiger of the Corps of Engineers and Dr. Dave Perkins of the USDA. We had received unofficial reports of an Alternaria affecting waterhyacinth in California as well as other locations. This represents our first collection of the fungus. Its pathogenic potential is still under evaluation.

55. With the completion of the preceding trips, we now have a fair idea of the disease picture as it occurs on waterhyacinth. Interestingly, the widest variety of disease have been found in the area of Puerto Rico and the Dominican Republic.

56. The two exotic pathogens that appear to have the most biocontrol potential are the waterhyacinth rust and the Helminthosporium (Bipolaris) on waterhyacinth. These have been studied the most extensively and are still being actively investigated.

57. Initial attempts to inoculate waterhyacinth with the rust pathogen, $U$. eichhorniae, were unsuccessful, possibly due to lack of proper environment. A variety of treatments to stimulate the germination of uredospores of waterhyacinth rust were tried. They were: hydration of spores for $24 \mathrm{hr}$, freezing $\left(-5^{\circ} \mathrm{C}\right.$ for $24 \mathrm{hr}$ ) or heating (for $3 \mathrm{~min}$ at $55^{\circ} \mathrm{C}$ ) prior to hydration; and hydration in various concentrations of a mineral salts medium, in specialized media for growing rusts (obtained from Dr. C. A. Hollis), and in 0.1 percent solution of Tween 20. All these treatments failed to stimulate spores of $U$. eichhornia to germinate. Hydration in dilute ( 0.0025 to 0.025 percent) aqueous solutions of nonanol and octanol stimulated less than 1 percent of the spores to germinate.

58. After this initial failure, Charudattan again visited Argentina, Uruguay, Paraguay, and Brazil from 12 October through 8 November 1975, to collect spore samples of waterhyacinth rust, Uredo eichhorniae. As part of the general information he is seeking on rusts of Pontederiaceae, he also makes collections of Uromyces pontederiae on Pontederia cordata, P. lanceolata, and Eichhornia azurea. An apparently new rust on Reussia subovata was also discovered in the Missiones province of Argentina. Its relation to $U$. eichhorniae, $U$. pontederiae, and Uromyces heterantherae is being studied. The taxonomic study of these rusts would be vital to the host-specificity tests on U. eichhorniae.

59. A sample of $U$. eichhorniae from Dique Lujan, Campana, Argentina, was successfully inoculated onto waterhyacinth from Florida in greenhouse tests. Several additional techniques of spore germination were tried on U. eichhorniae. These included varying periods of hydration of uredospors, heat-shock, various temperatures, and incubation with volatile alcohols, synthetic media, or host leafextracts. Freezing spores for periods up to $24 \mathrm{hr}$ prior to hydration seems to trigger spore germination and subsequent infection of host. Use of very freshly collected uredospores also seemed vital to successful germination and host-infection.

60. The possible lack of prolonged contact between uredospores and the waxy leaves of waterhyacinth was considered partly responsible for failure of infections. Hence, undiluted glycerine and three different oils, namely heavy paraffin oil, citrus oil, and Visko-Rhap mineral oil, were tested as sticking agents in inoculations with $U$. eichhorniae. The oils were less desirable than glycerine. The less viscous citrus oil and Visko-Rhap proved toxic to waterhyacinth leaves, causing burn damage. While mineral oil was nontoxic, it was suspected of creating a hydrophobic phase between spores and leaves and thus preventing spore germination. Glycerine proved to be a successful medium for spore inoculation. 
61. Close to 100 percent relative humidity following deposition of uredospores on leaves was necessary for infections. This was achieved by maintaining spores and plants in chambers containing saturated $\mathrm{CaSO}_{4} \cdot 2 \mathrm{H}_{2} \mathrm{O}$ solution.

62. Rust infection on inoculated waterhyacinth was visible in about two to three weeks after spore deposition. Development of uredosori was complete after the third week. During a two-week period following eruption of uredosori, several crops of spores have been observed.

63. Inoculations of waterhyacinths with $U$. pontederiae from Pontederia spp. and E. azurea are being attempted to determine cross infectivity among rusts of Pontederiaceae.

64. The isolate of Bipolaris identified as B. stenospila ${ }^{18}$ from the Dominican Republic was compared for its virulence with an isolate of Helminthosporium stenospilum Drechs. $(=B$. stenospila $)$ from the American Type Culture Collection. The former was significantly more virulent and destructive to waterhyacinth than the latter which was moderately pathogenic. In comparison, $H$. cynodontis, $H$. sacchari and $H$. sativum were weakly pathogenic while the following were nonpathogenic to waterhyacinth: $H$. maydis, $H$. victoriae, $H$. setariae and $H$. carbonum. Both $H$. sacchari and $H$. stenospila are sugarcane pathogens found in Florida and other sugarcane regions of the southeastern United States. Therefore, it is likely that we may find an isolate of B. stenospila in Florida that is more virulent on waterhyacinth than the type specimen of $H$. stenospila (Table 4).

\section{INTEGRATED CONTROL}

65. In cooperation with Dr. Perkins at Ft. Lauderdale, limited integrated controls tests using Acremonium zonatum and the insect Neochetinia eichhorniae were conducted. These tests indicated, though inconclusively, that increased damage resulted from the use of the two biotic agents together.

66. A more extensive integrated test was set in Lake Concordia, the week of 29 June 1975. This test, which is still in progress, is a cooperative effort with the Aquatic Plant Research Branch of the WES in Vicksburg and the Biocontrol Laboratory of the USDA in Gainesville. The object is to test the effectiveness of two plant pathogens and two insects, alone and in all possible combinations on 2-by 2-m aluminum frames containing waterhyacinths. The treatments are: (a) Arzama densa (insect), (b) Neochetinia eichhorniae (insect), (c) Cercospora rodmanii (plant pathogen), and (d) Acremonium zonatum (plant pathogen). Rates of treatment were: $A$. dens $a=40$ per cage; $N$. eichhorniae $=50$ per cage; Cercospora $=80 \mathrm{~g}$ wet weight mycelium and spores; and $A$. zonatum $=160$-g wet weight mycelium and spores. Plant pathogens were put on in split applications 24 and 25 June. One half of each inoculum batch was put on in approximately $2 \ell$ of water per plot 24 June. The following day the other half of the inoculum was sprayed on the plots. Insects were released two weeks later (10 July). At this time, infection was noted by both pathogens (personal communication with Neal Spencer, USDA, and Sam Shirley, WES).

67. The Lake Concordia experiment has been monitored at regular intervals during the growing season and will continue at least through the 1976 growing season.

68. Preliminary weighing data show that the four agents in combination cause a significant decrease in biomass accumulation. By mid-September, this weight of plants attacked by all four biotic agents was less than 50 percent of that of the check plants. Complete results of this test will be published upon its completion in 1976 . The preliminary results are very encouraging.

\section{CONCLUSION}

69. Significant advances have been made in realizing the goal of the utilization of plant pathogens 
in biocontrol programs for aquatic weeds. It is anticipated that the results of this study will help bring this goal to fruition within the next few years. The support of the U. S. Army Corps of Engineers has been a significant contributing factor in making these efforts possible.

\section{RECOMMENDATIONS}

70. The EPA-AIPS Workshop held at the University of Arkansas from 23 to 24 June 1975 recommended that:

a. APHIS and the Working Group on Natural Enemies evaluate proposals and make judgment in cooperation with the State Plant Regulation Agency of whether or not to import fungi for use in the Classical Biocontrol Strategy.

$b$. EPA develop guidelines for registration of fungi for use as mycoherbicides.

c. Policy be formulated to permit commercial firms to have limited term exclusivity to public use patents.

d. Advice and council of the American Phytopathological Society and other societies as appropriate, be sought. Identify expertise needed for the development of guidelines for registration of fungal pesticide products by EPA.

e. AIBS continue this workshop approach for development of specific registration criteria for biological pesticides.

In addition, the following study program was outlined.

a. Identify the fungus and determine its synonymy, genus, species, strain, and race.

b. Identify the target plant or organism and its synonymy and biology, genus, species, strain, and biotypes.

c. Determine the life cycle of the pathogen or that of the nearest representative perfect genus of the taxon. Investigate genetic stability.

d. Determine the disease cycle or etiology of the disease (seed borne, soil borne, wind borne, water borne, overwintering mechanism, motility, plant parts affected, chlorosis, necrosis, wilt, sterility).

$e$. Determine the epidemiology of the disease (cardinal temperatures for growth sporulation and durability in storage or the environment).

f. Determine geographic area over which the target species occurs and the distribution of the disease.

g. Make an intensive host range study beginning with related plant specified for all stages.

$h$. Characterize the components of the fungus as it will be employed in field tests (conidia, sclerotia, mycelium, sexual spores, sporangia, chlamydospores).

$i$. Characterize the material other than fungal material included in product.

j. Examine the toxicological properties of the product:

(1) Acute oral (2 animal species).

(2) Dermal (guinea pig).

(3) Respiratory (2 animal).

(4) Potential for mycotoxin production.

$k$. Determine effects on fish and wildlife.

l. Determine efficacy in field. 


\section{REFERENCES}

1. Zettler, F. W. and Freeman, T. E., "Plant Pathogens as Bio-Controls of Aquatic Weeds," Annual Review, Phytopathology, Vol 10, 1972, pp 455-470.

2. Freeman, T. E., Charudattan, R., and Zettler, F. W., "Biological Control of Water Weeds with Plant Pathogens," Publication No. 23, 1973, Water Resources Research Center, University of Florida, Gainesville, Fla.

3. Freeman, T. E. and Zettler, F. W., "Rhizoctonia Blight of Waterhyacinth," Phytopathology, Vol $61,1971, \mathrm{p} 892$.

4. Joyner, G. G. and Freeman, T. E., "Pathogenicity of Rhizoctonia solani to Aquatic Plants," Phytopathology, Vol 63, 1973, pp 681-685.

5. Freeman, T. E., "Survival of Sclerotia of Rhizoctonia solani in Lake Water," Plant Disease Reptr., Vol 57, 1973, pp 601-602.

6. Joyner, B. G., Characterization of a Rhizoctonia sp. Pathogenic to Aquatic Plants, M.S. Thesis, University of Florida, Gainesville, Fla., 1972.

7. Freeman, T. E. "Rhizoctoniosis of Aquatic Plants," Encyclopedia of Science and Technology Yearbook, McGraw-Hill, New York, 1975, pp 327-328.

8. Rintz, R. E., “Zonal Leafspot of Waterhyacinths," Hyacinth Control Journal, Vol 11, 1973, pp 4144.

9. Freeman, T. E. and Charudattan, R., "Occurrence of Cercospora piaropi on Waterhyacinth in Florida," Plant Disease Rptr., Vol 58, 1974, pp 277-278.

10. Conway, K. E., Freeman, T. E., and Charudattan, R., "The Fungal Flora of Waterhyacinths in Florida, Part I," Publication No. 30, 1974, Water Resources Research Center, University of Florida, Gainesville, Fla.

11. Conway, K. E., "Cercospera Rodmanii, A New Pathogen of Waterhyacinth with Biological Control Potential” (in preparation), Canadian Journal Bot.

12. Hill, H. R. and Zettler, F. W., "A Virus-Like Stunting Disease of Alligatorweed from Florida," Phytopathology, Vol 63, p 443.

13. Lin, C. Y. and Charudattan, R., "Sigmoidea sp., A New Pathogenic Aquatic Hyphomycete of Waterhyacinth," Proceedings, American Phytopathological Society, Vol 2, 1975, p 137.

14. Charudattan, R. and Conway, K. E., “Mycoleptodiscus terrestris Leaf-Spot on Waterhyacinth," Plant Dis. Reptr., Vol 66, 1975, pp 77-80.

15. Conway, K. E. and Kimbrough, J. W., “A New Doratomyces from Waterhyacinth," Mycotaxon, Vol 2, 1975, pp 127-131.

16. Charudattan, R., "Pathogenicity of Fungi and Bacteria from India to Hydrilla and Waterhyacinth," Hyacinth Contr. Journal, Vol 11, 1973, pp 44-48.

17. Charudattan, R. and Conway, K. E., "Comparison of Uredo eichhorniae, the Waterhyacinth Rust with Uromyces pontederiae," Mycologia, Vol 67, 1975, pp 653-657.

18. Charudattan, R., Conway, K. E., and Freeman, T. E., "A Blight of Waterhyacinth, Eichhornia crassipes Caused by Bipolaris stenospila (Helminthosporium stenospilum)," Proceedings, Phytopathology Society, Vol 2, 1975, p 65. 


\section{BIBLIOGRAPHY}

Charudattan, R. and Lin, C. Y., "Isolates of Penicillium, Asperigillus, and Trichoderma Toxic to Aquatic Plants," Proceedings, EWRC Fourth International Symposium of Aquatic Weeds, Vienna, 1974, pp 142-143.

, "Penicillium, Aspergillus, and Trichoderma Isolates Toxic to Hydrilla and Other Aquatic Plants," Hyacinth Control Journal, Vol 12, 1973, pp 70-73.

Charudattan, R. et al., "Studies on the Use of Plant Pathogens in Biological Control of Aquatic Weeds in Florida," Proceedings, EWRC Fourth International Symposium on Aquatic Weeds, Vienna, 1974, pp 144-151.

Charudattan, R., "Evaluation of Foreign Pathogens as Biocontrols of Hydrilla and Waterhyacinth in the U. S. A.," Proceedings, Second International Congress of Plant Pathology, 1973, Abstract 0390; also Reprint No. 3, WSSA Newsletter, Vol 2, 1974, p 11.

, "Use of Plant Pathogens to Control Aquatic Weeds," Impact of the Use of Microorganisms on the Aquatic Environment, Ecological Research Series, U. S. Environmental Protection Agency, Corvallis, Oreg., 1975.

, "Weed Control with Plant Pathogens," Agrichemical Age, Jan-Feb 1975.

Conway, K. E., "Procedures Used to Test Endemic Plant Pathogens for Biological Control of Waterhyacinth," Proceedings, Phytopathology Society, Vol 2, 1974, p 31.

Freeman, T. E. and Zettler, F. W., "A Disease of Waterhyacinth with Biological Control Potential," Abstracts of 1972 Meeting of Weed Science Society of America, p 61.

Freeman, T. E., Charudattan, R., and Conway, K. E., "Use of Plant Pathogens for Bioregulation of Aquatic Macrophytes," Proceedings, EPA Conference, Biological Control for Water Quality Enhancement, 1975.

Freeman, T. E., Zettler, F. W., and Charudattan, R., "Phytopathogens as Biocontrols for Aquatic Weeds," PANS., Vol 20, 1974, pp 181-185.

"Utilization of Phytopathogens as Biocontrols for Aquatic Weeds," Third

International Symposium on Biological Control of Aquatic Weeds, Montpellier, France, 1973; also published in Proceedings, Conference on Integrated Systems of Aquatic Plant Control, 1974, pp 97-102.

Gangstad, E. O. et al., "Aquatic Plant Control Program; Aquatic Weed Control with Plant Pathogens," Report 8, Dec 1974, U. S. Army Engineer Waterways Experiment Station, CE, Vicksburg, Miss.

Goeden, R. E. et al., "Present Status of Projects on the Biocontrol of Weeds with Insects and Plant Pathogens in the United States and Canada," Weed Science, Vol 22, 1974, pp 490-495.

Hayslip, H. F. and Zettler, F. W., "Past and Current Research on Diseases of Eurasian Watermilfoil (Myriophyllum spicatum L.)," Hyacinth Control Journal, Vol 11, 1973, pp 38-40.

Hayslip, H. F., Evaluation of Plant Pathogens as Biocontrols of Eurasian Watermilfoil (Myriophyllum spicatum L.), M.S. Thesis, University of Florida, Gainesville, Fla., 1972.

Hill, H. R. and Rintz, R. E., "Observations of Declining Water Lettuce Populations in Lake Izabel, Guatemala,” Proceedings, Southern Weed Science Society, Vol 25, 1972, pp 374-380.

Hill, H. R., Survey and Evaluation of Plant Pathogens of Alligatorweed (Alternanthera philoxeroides(Mart.) Griseb.), M.S. Thesis, University of Florida, Gainesville, Fla., 1972.

Hill, H. R., Zettler, F. W., and Freeman, T. E., "Plant Pathogens with Potential for Biological Control of Aquatic Weeds," Proceedings, Southern Weed Science Society, Vol 25, 1972, p 388.

Ridings, W. H. and Zettler, F. W., "Aphanomyces Blight of Amazon Sword Plant," Phytopathology, Vol 62, 1972, Abstract, p 806; also Vol 63, 1973, pp 289-295. 
Rintz, R. E. and Freeman, T. E., "Fusarium roseum Pathogenic to Waterhyacinth in Florida," Phytopathology, Vol 62, 1972, p 806.

Rintz, R. E., Location, Identification and Characterization of Pathogens of the Waterhyacinth, Ph. D. Dissertation, University of Florida, Gainesville, Fla., 1973.

Zettler, F. W. and Freeman, T. E., "Potential for the Use of Plant Pathogens as Biocontrol Agents of Weeds," Proceedings, Second International Congress of Plant Pathology, St. Paul, Minn., 1973. 
Table 1

Infection of Crop Plants by “Acremonium zonatum" and "Rhizoctonia solani” After Spray Inoculation with a Mycelial and Spore Suspensions

\begin{tabular}{|c|c|c|c|}
\hline \multirow[b]{2}{*}{ Crop } & \multirow[b]{2}{*}{ Variety } & \multicolumn{2}{|c|}{ Infection } \\
\hline & & "R. solani" & "A. zonatum" \\
\hline Cabbage & Charleston Wakefield & $--*$ & -- \\
\hline Canteloupe & Hales Best Jumbo & $\mathrm{x}^{* *}$ & -- \\
\hline Carrot & Imperator & -- & -- \\
\hline Celery & Giant Pascal & -- & -- \\
\hline Collard & Georgia & -- & -- \\
\hline Cucumber & Poinsett & $\mathrm{xx}^{\dagger}$ & -- \\
\hline Eggplant & Forida Market & -- & -- \\
\hline Endive & Green curled & -- & -- \\
\hline Escarole & Batavian & -- & -- \\
\hline Field corn & PAB 751 & -- & -- \\
\hline Grapefruit & Duncan & -- & -- \\
\hline Irish potato & Sebago & -- & -- \\
\hline Lettuce & Great Lake & -- & -- \\
\hline Lima bean & Henderson & -- & -- \\
\hline Mustard & Florida Broadleaf & -- & -- \\
\hline Oats & Fulghum & -- & -- \\
\hline Okra & Clemson Spineless & -- & -- \\
\hline Onion & White Globe & -- & -- \\
\hline Orange & Temple & -- & -- \\
\hline Peanut & Florunner & -- & -- \\
\hline Pole bean & Kentucky Wonder & $\mathrm{xxx}_{\dagger}^{\dagger}$ & -- \\
\hline Radish & Scarlet Globe & -- & -- \\
\hline Rye & Weser & -- & -- \\
\hline Slash pine & -- & -- & -- \\
\hline Snap beans & Harvester & -- & -- \\
\hline Soybeans & Bragg & -- & -- \\
\hline Southern peas & Cream 40 & -- & -- \\
\hline Squash & Early Summer Crookneck & -- & -- \\
\hline Strawberry & Florida 90 & -- & -- \\
\hline Sugarcane & CL 41-223 & -- & -- \\
\hline Sweet corn & Silver Queen & -- & -- \\
\hline Sweet pepper & Yolo L & - & -- \\
\hline Sweet potato & $?$ & - & -- \\
\hline Tangerine & Dancy & -- & -- \\
\hline Tobacco & Turkish NN & -- & -- \\
\hline \multirow[t]{4}{*}{ Tomato } & Homestead & -- & -- \\
\hline & Manalucia & -- & -- \\
\hline & Walter & -- & -- \\
\hline & MH 1 & -- & -- \\
\hline \multirow[t]{2}{*}{ Watermelon } & Congo & $\mathrm{xxx}$ & -- \\
\hline & Charleston Grey & $\mathrm{xxx}$ & -- \\
\hline Wheat & Holden & -- & -- \\
\hline
\end{tabular}

* No infection.

** Moderate infection.

+ Severe infection.

$\dagger$ Mild infection. 
Table 2

Plants Included in Greenhouse and Field Host Range Test for Susceptibility to "Cercospera Rodmanii"

\begin{tabular}{|c|c|c|}
\hline Plant & Variety or Description & Resistance \\
\hline Avocado & -- & $--^{*}$ \\
\hline Beans & Harvester & -- \\
\hline Beans & Lima Fordhook bush & -- \\
\hline Beans & Runner Kentucky Wonder (pole type) & -- \\
\hline Beans & Speckled butter Jackson Wonder & $-\cdot$ \\
\hline Beans & White baby lima Henderson bush & -- \\
\hline Beets & Detroit Dark Red & -- \\
\hline Cabbage & Charleston Wakefield & -- \\
\hline Canteloupe & Hale's Best & - \\
\hline Carrots & Imperator & $-\cdot$ \\
\hline $\begin{array}{l}\text { Celery } \\
\text { Collard }\end{array}$ & Giant Pascal & - \\
\hline $\begin{array}{l}\text { Collard } \\
\text { Colocasia } \mathrm{sp} .\end{array}$ & Georgia & -- \\
\hline $\begin{array}{l}\text { Colocasia sp. } \\
\text { Corn }\end{array}$ & & $\begin{array}{l}-- \\
--\end{array}$ \\
\hline Corn & $\begin{array}{l}\text { Field corn PAG } 751 \\
\text { Funks } 5945^{* *}\end{array}$ & -- \\
\hline Corn & Funks $4762^{* *}$ & 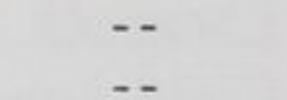 \\
\hline Corn & Florida Sweet & -- \\
\hline Corn & Golden Hybrid NK $199^{+}$ & -- \\
\hline Corn & Silver Queen & -- \\
\hline Cotton & Sea Island & -- \\
\hline Cotton & DPL $16 * *$ & -- \\
\hline Cotton & Stoneville $213^{* *}$ & -- \\
\hline Cowpeas & Zipper Cream & - \\
\hline Cucumber & Pickling F1 hybrid ${ }^{+}$ & -- \\
\hline Eggplant & Florida Market & -- \\
\hline Hydrocotyle umbellata** & स & - \\
\hline Grapefruit & -- & - \\
\hline Lemon & -- & -- \\
\hline Lettuce & Great Lakes bibb (sporulated on senescent leaves) & -- \\
\hline Red mangrove & -- & -- \\
\hline Mustard & Florida Broadleaf & -- \\
\hline Oats & Fulghum & -- \\
\hline Okra & Clemson Spineless & -- \\
\hline Onion & Purple & -- \\
\hline Onion & Red & -- \\
\hline Onion & White & -- \\
\hline Orange & Sour & $-\cdot$ \\
\hline Orange & Sweet & -- \\
\hline Peanuts & Florunner & $-\cdot$ \\
\hline Peas & Cream Acre & $-\cdot$ \\
\hline Peppers & Banana & -- \\
\hline Peppers & Hot Hungarian & $\cdots$ \\
\hline Pine tree & Slash & -- \\
\hline Pontederia cordata & Irich Red I a Soda & - \\
\hline Potatoes & Irish Red La Soda & - \\
\hline Pyracantha & Scarlet Red Globe & - \\
\hline $\begin{array}{l}\text { Radishes } \\
\text { Rice }\end{array}$ & $\begin{array}{l}\text { Scarlet Red Globe } \\
\text { Saturn** }\end{array}$ & - \\
\hline $\begin{array}{l}\text { Rice } \\
\text { Rye }\end{array}$ & $\begin{array}{l}\text { Saturn** } \\
\text { Weser }\end{array}$ & -. \\
\hline $\begin{array}{l}\text { Rye } \\
\text { Squash }\end{array}$ & $\begin{array}{l}\text { Weser } \\
\text { Early Summer Crookneck }\end{array}$ & -. \\
\hline $\begin{array}{l}\text { Squash } \\
\text { Strawberry }\end{array}$ & & -- \\
\hline $\begin{array}{l}\text { Strawberry } \\
\text { Soybeans }\end{array}$ & $\begin{array}{l}\text { Florida } 90 \\
\text { Bragg** }\end{array}$ & -- \\
\hline $\begin{array}{l}\text { Soybeans } \\
\text { Soybean }\end{array}$ & $\begin{array}{l}\text { Bragg** } \\
\text { Davis }\end{array}$ & -. \\
\hline $\begin{array}{l}\text { Soybean } \\
\text { Sugarcane }\end{array}$ & - & -- \\
\hline Sweet potatoes & Georgia Red & -. \\
\hline Tangerine & - & -- \\
\hline Tobacco & Turkish & -- \\
\hline Tomatoes & Homestead & -- \\
\hline Tomatoes & MH-1 & -- \\
\hline Tomatoes & Manalucia** & -- \\
\hline Tomatoes & Walter & -. \\
\hline Waterhyacinth & Inoculum check & $-\cdot$ \\
\hline Watermelon & Charleston Grey & -- \\
\hline Watermelon & Crimson Sweet ${ }^{\dagger}$ & $-\cdot$ \\
\hline Wheat & Holden & $-\cdot$ \\
\hline
\end{tabular}

* Not susceptible.

** Greenhouse only.

$\dagger$ Field only. 
Table 3

\section{Fungi Found Associated with Waterhyacinth}

During Winter and Spring Months

\begin{tabular}{|c|c|}
\hline Fungi & Pathogenicity \\
\hline \multicolumn{2}{|l|}{$\begin{array}{l}\text { Subdivision } \\
\text { Ascomycotina }\end{array}$} \\
\hline \multicolumn{2}{|l|}{ Class-Pyrenomycetes } \\
\hline 1. Melanospora $\mathrm{sp}$. & None \\
\hline \multicolumn{2}{|l|}{ Class-Loculoascomycetes } \\
\hline $\begin{array}{l}\text { 2. Leptosphaerulina } \mathrm{sp} . \\
\text { 3a. Didymella exigua } \\
\text { b. Ascochyta (imperfect stage) } \\
\text { 4. Mycosphaerella } \mathrm{sp} .\end{array}$ & $\begin{array}{l}\text { None } \\
\text { None } \\
\text { None } \\
\text { Slight }\end{array}$ \\
\hline \multicolumn{2}{|l|}{ Deuteuromycotina } \\
\hline \multicolumn{2}{|l|}{ Class-Coelomycetes } \\
\hline $\begin{array}{l}\text { 5. Phoma spp. } \\
\text { 6. Botryodiploidea } \mathrm{sp} .\end{array}$ & $\begin{array}{l}\text { Varies-moderate to none } \\
\text { Slight }\end{array}$ \\
\hline \multicolumn{2}{|l|}{ Class-Hyphomycetes } \\
\hline 7. Unknown synnematal fungus & None \\
\hline 8. Mycoleptodiscus terrestris & Slight to none \\
\hline 9. Myrothecium cintum & None \\
\hline 10. Epicoccum purpurascens & None \\
\hline 11. Alternaria spp. & None \\
\hline 12a. Aspergillus flavus & None \\
\hline b. Aspergillus niger & None \\
\hline 13. Acremonium zonatum & Good-excellent \\
\hline 14. Bipolaris spp. & Good-under investigation \\
\hline 15. Cercospora sp. & Good-excellent \\
\hline 16. Cladosporium spp. & None \\
\hline 17a. Curvularia brachyspora & None \\
\hline b. Curvularia penniseti & Slight \\
\hline 18. Dendryphiella infuscans & Not tested \\
\hline 19. Exserohilum prolatum & Under investigation \\
\hline 20. Memnoniella subsimplex & Not tested \\
\hline 21. Perionia echinochloae & Slight \\
\hline 22. Pithomyces chartarum & None \\
\hline 23a. Nigrospora oryzae & None \\
\hline b. Nigrospora sphaerica & None \\
\hline 24. Thysanophora longispora & None \\
\hline 25. Scolecobasidium humicola & None \\
\hline 26. Stemphylium vericarium & Under investigation \\
\hline 27. Ustilaginoidea $\mathrm{sp} .(?)$ & Not tested \\
\hline
\end{tabular}


Table 4

Virulence of "Bipolaris stenospila" from the Dominican Republic (353), American Type Culture Collection (13447) and Florida (14 b) to

Waterhyacinth and Four Graminaceous Plants

\begin{tabular}{|c|c|c|c|c|c|}
\hline Isolate & Waterhyacinth & Bermudagrass & Sugarcane & Corn* & Oat* \\
\hline 353 & $4+* *$ & $3+$ & $2+$ & 0 & 0 \\
\hline 13447 & $2+$ & $2+$ & $2+$ & Not tested & Not tested \\
\hline $14 \mathrm{~b}$ & $2+$ & $3+$ & $2+$ & Not tested & Not tested \\
\hline
\end{tabular}

* Varieties resistant and susceptible to Helminthosporium were tested.

** Rating of pathogenicity was based on the degree of damage. Replicated three times (plant). Experiment repeated twice with grasses and four times with waterhyacinth. 